\title{
Ljubica JANČEVA
}

Institute of National History, Skopje

jancevaljubica@yahoo.com

\section{THE PRINCIPLES OF ASNOM}

\section{AND THE CONSTITUTIONAL HISTORIC LEGACY FOR THE "FRAMEWORK” REPUBLIC OF MACEDONIA}

ABSTRACT The Republic of Macedonia is a state of highest democratic standards as reflected in the provisions of its constitution and laws concerning relations between various ethnic, religious and cultural communities. The multiethnic, multicultural and pluralistic nature of the Republic of Macedonia is visible and implemented in all spheres of social life. The human rights declaration adopted at the first sitting of the ASNOM ${ }^{1}$ is the basic document which defines the multiethnic nature of the just country established, much like the constitutional provisions of the DFM/LRM/SRM² (1946, 1963 and 1974 respectively), as well as the 1991 constitution of the independent and sovereign Republic of Macedonia, where the Republic of Macedonia was defined asa nation (Macedonian) state with extensive rights granted to ethnic, national and religious minorities. Representatives of ethnic communities sitting in the parliament of the Republic of Macedonia, particularly Albanians, demanded that they be granted the status of the other equal nation. Dissatisfaction escalated and in 2001, i.e. a decade after the Republic of Macedonia had become independent, took a military form, and the conflict resolution was going towards the federalisation of the country. In 2001, a framework (Ohrid) agreement was signed brokered by international partners. Along with the accord, the notion of a nation state was abandoned and

ASNOM - Anti-fascist Assembly for the National Liberation of Macedonia, which in 1944 proclaimed the birth of Macedoniaas one of the republics within the Yugoslav federation (Ed.).

2 DFM - Democratic Federal Macedonia, LRM - People's Republic of Macedonia, SRM - Socialist Republic of Macedonia (Ed.). 
consequently also practising majority democracy, a model characteristic of states that are ethnically homogenous. The country was redefined as pluralist, multiethnic and multicultural; as a result instead of majority democracy a "division-of-power model" (in practice the term "participatory democracy" is used) was applied, characteristic of multiethnic communities, as prevention against interethnic confrontation.

Key-words: Republic of Macedonia, Antifascist Assembly on National Liberation of Macedonia (ASNOM), Constitution, Ohrid Framework Agreement, Macedonians, Albanians

$\mathrm{T}$ he Republic of Macedonia is a state with high democratic values in terms of the relations among the different ethnic, religious and cultural communities which are incorporated in the Constitution and the laws. The multi-ethnic, multicultural and pluralistic character of the Republic of Macedonia is visible and applied in all social spheres. By placing the emphasis on the multi-ethnic and multicultural, and pluralistic character of Macedonia, we hereby disclaim ourselves from the term "divided Macedonia", a term present in public discourse after the signing of the Ohrid (Framework) Agreement which is used in political theory for societies with more ethnic groups. ${ }^{3}$

The Ohrid (Framework) Agreement was signed in 2001 under the auspices of the international factor. Thus the concept of national state was largely abandoned as well as practicing majority democracy, a model typical for ethnically homogenous states. The states were redefined as pluralistic, multiethnic, multicultural and subsequently the majority democracy was replaced by the so-called "model power sharing" (the term participative democracy is also used), typical for multiethnic communities and in order to prevent multiethnic conflicts. ${ }^{4}$

Why to opt for framework agreement and why such contents? In theory, its application was impossible, but in practice it was different.

In an attempt to find answers to the questions the analysis is focused on the Constitution of the Republic of Macedonia from 1991, which proclaimed the concept of national (unitary) state. This concept, typical for states which do not have other nations aside of the main nation, failed to promote democracy and caused dissatisfaction among the ethnic communities primarily among the Albanian community, which a decade later got militant characteristics with tendency for federalization of the

М. Малеска, $\Lambda$. Христова, Ј. Ананиев, 'Споделување на власта нов модел на одлучување во мултикултурните општини', New Balkan Politics, No. 10 (2006-2007).

4 In theory the concept of power sharing is based on several basic principles and institutions: 1. Large coalition in power; 2. Different degrees of territorial autonomy; 3. Proportional that is equitable representation of the minorities in the state bodies (administration, army and police); 4 . Right to minority veto; 5 . Proportional election model and written constitution. Ibid. 
state. However, from historical perspective, the multiethnic character of the state has deep roots, so that the analysis is based on the First session of ASNOM (Anti-fascist Assembly for the National Liberation of Macedonia), as a starting point since with the documents adopted during the session, the Macedonian state was constituted as federal unit within the Yugoslav federation as well as because of the fact that the principles of ASNOM proclaimed permanent processes initiated with Ilinden 1903 and which are based on multiethnicity. ${ }^{5}$

The ASNOM commitments on the multiethnic character of the state are primarily supported by the adoption of the Declaration on the Human Rights ${ }^{6}$, a document of 10 articles containing the fundamental principles and pillars of a future modern, European, democratic and free civil life of the new Macedonian state. It also confirms its conceptualization on the principles of the contemporary civil concept of regulation of the society by affirming the values of the personal civil rights and duties.

Article 1 of the Declaration is crucial to our analysis, as it states: "All citizens of the federal Macedonian state shall be equal before the laws regardless of their nationality, sex, race, and confession" as well as article 2, stating that "National minorities in Macedonia shall enjoy all their rights to free national life". Even though only two articles refer directly to the "national minorities", it does not diminish its historic importance, but on the contrary, in such a constellation (prior to the liberation) the political and military leadership at that time maps Macedonia as a multiethnic state.

The multiethnic character of Macedonia is a fact, and as in the Declaration, it is reflected in the constitutive documents on which the post-war constitutional and legal development of Macedonia is based. In the so-called post-war, communist, that is, self-management-socialistic period, the relations among the majority - the people and the minority - nationalities were adequately defined in the constitutions.

In the Constitution from $1946^{7}$ and in line with the Constitution of the FPRY (Federal People Republic of Yugoslavia) ${ }^{8}$, the PRM (People Republic of Macedonia) is defined as People's Republic in which the power comes from and belongs to the people. It is important that regardless of the multiethnic character, the emphasis is placed on the peoples that are the people, while the nationalities are only mentioned in two articles of the Constitution. Article 12 states that national minorities will enjoy all rights and protection of their cultural development and freedom to use their language, while article 20 provides that all citizens are guaranteed freedom and equality before the laws

5 In addition to explaining the goals of the uprising, the Krushevo Manifesto sends an appeal for cooperation and participation in the uprising to the non-Christian Turkish and Albanian population by calling them "our brothers by homeland and suffering". These words clearly indicate the multiethnic uprising concept for rights and freedoms, that is rights to equality of all citizens before the law, and freedom which in the historical context of the document implicates national freedom of those ethnic communities which it did not have within the Ottoman Empire.

6 Архив на Македонија, Скопје, 1984, АСНОМ, т. 1, кн. 1, Аокументи од Првото и Второто заседание на АСНОМ, док. 41, 157.

7 Службен весник на НРМ, III/1, Скопје, 1947.

8 Службен лист на ФНРЈ, II/10, БеограА, 1946. 
regardless of their nationality, belonging, religion and race. Unlike the first, with the Constitution from 1963, the multiethnic character of the state gets a different dimension. Within chapter III of the Coinstitution which defines the social and political regulation, the rights of the peoples-national minorities are elaborated in a separate part. Namely, in accordance with article 72, nationalities in the SRM (Socialist Republic of Macedonia), are equal and have same rights and duties as the Macedonians. ${ }^{9}$ The Constitution also guarantees the right to free expression of their culture and identity as well as the establishment of institutions to exercise such rights. As far as the use of the mother tongue, its use in the education, administration and judicial bodies is concerned, these issues are regulated separately. ${ }^{10}$

A positive development for the multinational character of the state is the adoption of the Constitution of SRM from 1974 whose preamble defines SRM as "national state of the Macedonian people and state of the Albanian and Turkish nationalities within it". ${ }^{11}$ The Constitution in separate parts and articles defines the "rights of the nationalities" in different areas as well as the proportional representation of the nationalities in the state and public bodies. In that context, during the $70 \mathrm{~s}$ and 80 s, a series of measures and activities were taken for cultural and educational affirmation of ethnic communities. In documents of all levels, as well as the documents of the Communist Party (SK) a positive trend was visible for cultural affirmation of ethnic communities. Positive results were noted in the activities of houses of culture, education facilities, the Theatre of Nationalities, news and publishing, mass media, etc. The role of the local government was a positive addition to the trend. Statutes of multietnical municipalities included provisions that regulated the issue of education, culture, cultural heritage, equality of letters and languages of ethnic communities in the Macedonian language, the use of flags, proportional representation in municipal assemblies, etc.

The Constitution stipulates maximal equality of the Macedonian people and the nationalities whereby article 183 envisages the establishment of committee for relations among the nationalities, which would monitor the fulfillment of equality and other rights set forth by the Constitution and laws and would propose measures and modalities for their implementation. ${ }^{12}$

The Constitution defined in line with the Western European criteria regulated the status of the nationalities. The proclaimed constitutional principles enabled the multiethnic functioning of Macedonia until 1991.

Службен весник на СРМ, XIX/15, Скопје, 1963.

10 In the populated areas with larger number of members of the nationalities, the education is imparted in their mother tongue, while all more important acts of the local self-government unit and the judicial decisions are published in the language of the nationality as well. 'Устав на СРМ', Службен весник на СРМ, XIX/15, Скопје, 1963.

11 Службен весник на СРМ, XXX/7, Скопје, 1974.

12 The Commission was established in the Assembly of the SRM and in the assemblies of the municipalities where the nationalities lived. An equal number of representatives from the different nationalities was elected in its composition. Ibid. 
The new Constitution from 1991 adopted in new historical developments is continuity in the Macedonian constitutional and legal political tradition.

Unlike the previous ones, the accent in this Constitution is placed on the individual rights and freedoms of the citizens as a result of the psycho-political climate which marked the 90s.

The preamble defines Macedonia as "national state of the Macedonian people in which complete civil equality and coexistence with the Albanians, Turks, Vlachs, Roma and other ethnic communities is provided [...]". The rights of the nationalities in Macedonia are regulated in several chapters in the Constitution, in accordance with the provisions from the Declaration on the Rights of the Citizens belonging to the Ethnic Communities adopted by the UN (United Nations) General Assembly in December 1992 which are fully incorporated in the Constitution. ${ }^{13}$ The ethnic communities enjoy a constitutionally guaranteed right to obligatory primary and secondary education in the mother tongue, the official use of the mother tongue in the municipalities where they represent the majority and many other rights which contributed towards the development of their identity and emancipation. However, many issues remain open...

Namely, the concept of national (unitary) state was introduced with the Constitution. The Macedonian language became the only official language, the Macedonian Orthodox Church received the status of the national church. The Constitution was based on several principles: constitution of independent and sovereign state; constitution of civil and democratic state; constitution of legal and social state; constitution for coexistence of the Macedonian people and the nationalities living in it. ${ }^{14}$

According to the character it was liberal-democratic, supplemented with social and regulatory functions of the state. With the new Constitution, Macedonia separated from the Yugoslav federalism which meant unitarity. ${ }^{15}$ One of the "authors" prof. Ljubomir D. Frchkovski qualified the Constitution as European and drafted in line with the European standards. ${ }^{16}$

However, in a constellation of democracy the accepted concept of national state (arising from the preamble) with the existence of another numerous population which is nationally awaken can result in conflict. In such circumstances it would be difficult to

13 М. Аимитријевски, Ф. Јанчева, 'Принципите на АСНОМ и Аекларацијата за човековите права' in Ц. Грозданов (ed.), Република Македонија - 60 години по АСНОМ. Зборник од научниот собир по повод шеесетгодишнината од АСНОМ, одржан во Скопје на 15-16 декември 2004 година, Скопје 2005, р. 243.

С. Шкариќ, Уставно право, Vol. 1, Скопје 1994, p. 236.

15 Ь. Јанчева, Последните дещении со СФРЈ, Скопје 2012, p. 148.

16 "The fortunate circumstance is that the national tension which exists in Macedonia is only located in the preamble of the Constitution in relation to the historical continuity of the Macedonian statehood. The Constitution itself has a typical geographic definition of the state without national tensions. The comments that the use of the term national minority means degradation of part of the population are unfounded if the rights of the national minorities provided under the Constitution are taken into consideration." Ibid. 
implement democracy, but not impossible. ${ }^{17}$ The representatives of the ethnic communities in the Assembly of the Republic of Macedonia, the Albanians primarily were not satisfied with the constitutional solutions. They wanted more rights that those ensured in the single-party system and they constantly emphasized in the Assembly the need for more rights to be provided to the ethnic communities, especially the Albanians requiring the status of second equal people. ${ }^{18}$ They did not vote for the adoption of the Constitution.

Hence, when the domination of the Macedonians in the Parliament blocked the process of articulation of the Albanians' interests in the state politics, the situation spilled over on the streets and the 2001 armed conflict took place. ${ }^{19}$

It can be concluded that by opting for strategy characteristic for states in which there is no other nation along with the majority, we adopted the 1991 Constitution which did not only fail to enhance democracy, but on the contrary, one decade later we had a dissatisfied Albanian population.

The momentum for democratic consolidation was there. The Ohrid Agreement mediated by the international factor, was signed and the armed conflict was stopped.

The concept of Macedonia as a national state was largely abandoned with the Agreement, while the state was redefined as multinational. The democratic consolidation was supported by the application of consensual democracy as a model which would ensure the necessary ethnic balance at all levels of ethnic decision making on the Macedonian political scene.

The Ohrid Agreement was a compromise. Both sides gave up on some of their requirements. It was based on several principles: complete and unconditional rejection of the use of violence for the accomplishment of political goals; guarantee of sovereignty, territorial integrity and unity of Macedonia; multiethnic character of the state reflected in all spheres of public life and state institutions; development of decentralized government; development of local self-government and application of the provisions of the European Convention on Local Self-Government; equitable representation of national communities in the public administration; right to veto by the ethnic communities when deciding on issues related to their interests; and the right to veto upon adoption of the Law on Local Self-Government and municipal borders. ${ }^{20}$

17 In the process of the adoption of the Constitution, the suggestions by the expert team which prepared the Constitution were accepted. They referred to article 78 in regard to the Council on the Interethnic Relations and the need of establishing a mechanism for consensus of the collectives for some legislative decisions.

18 The parliamentary group of the Party for Democratic Prosperity (PDP) submitted the Declaration on the equal status of the Macedonians and Albanians. The Declaration was not adopted since the relations proposed within it can only regulated by the Constitution. Those are relations of equal citizens, rights of certain nationality and national collectives which live in Macedonia and any parallel of the Constitution and the Declaration is not admissible. Ibid., p. 145.

19 А. Малески, 'Причини за една војна (Македонија 2001)', New Balkan Politics, No. 7-8 (2004).

20 М. Малеска, 'Болни соочувања (причините и последиците од безбедносната криза во Македонија)', New Balkan Politics, No. 5 (2003). 
The provisions from the Agreement resulted into the constitutional amendments from $2001{ }^{21}$ As it was stated by one of the negotiation mediators François Léotard in an interview "the agreement on paper is not sufficient, a mutual and genuine acknowledgment of the communities is needed; actions must follow words", the implementation of the Agreement started.

The Ohrid Agreement was characterized by many as controversial, capitulating and extorted with utopian provisions; it is one of the most significant Macedonian assets, a confirmation for Macedonia as a state with highest achievements on the Balkans in promoting the relations among different ethnic, religious and cultural communities. Moreover, some analysts consider it as one of the least utilized resources of Macedonia. ${ }^{22}$

It remains unknown if the Badinter majority rule is applied in the everyday parliamentary practice of other states (the right to ethnic veto). Moreover, if we take into consideration that some EU Member States do not acknowledge the reality that in some parts of their state ethnic communities live, neither they recognize their collective rights, the picture of Macedonia gets a new dimension. The failure of the Ohrid Agreement would be a confirmation for all those who are not ready for the democratic advancement of the Republic of Macedonia as a multicultural and multiethnic society. Thus the possibilities for "impairment of the document" on the indivisibility of Macedonia confirmed by the agreement signed by the most relevant political representatives of the Macedonian and Albanian community and the international community would be rejected.

Our conclusion is based on the above-mentioned. The principles of ASNOM provide the foundation, while the Ohrid Agreement is the product with which Macedonia shows that good interethnic relations are a guarantee for the development of democracy, economic stability, territorial integrity and Euro-Atlantic integration.

\section{BIBLIOGRAPHY}

Архив на Македонија, Скопје, 1984, АСНОМ, т. 1, кн. 1, Аокументи од Првото и Второто заседание на АСНОМ, Аок. 41.

Службен лист на ФНРЈ, II/10, БеограА, 1946.

Службен весник на НРМ, III/1, Скопје, 1947.

Службен весник на СРМ, XIX/15, Скопје, 1963.

Службен весник на СРМ, ХXX/7, Скопје, 1974.

21 The Constitutional amendments I-XVIII, refer to the Constitution's Preamble and are related to the use of the ethnic communities (their language, official under which terms), representation in the state and public institutions, cultural rights etc.

22 "The Least Utilized Resources of Macedonia are the Ohrid Agreement, the Ohrid Lake, and the river of Vardar. It is the largest Macedonian political, economic, strategic and unfortunately still dead capital.' Е. Ризанов, 'Македонски мртов капитак', Утрински весник, 7 Мау 2010. 
Аимитријевски М., Јанчева Ф., 'Принципите на АСНОМ и Аекцарацијата за човековите права' іп Ц. Грозданов (еd.), Република Македонија - 60 години по АСНОМ. Зборник од научниот собир по повод шеесетгодишнината од АСНОМ, одржан во Скопје на 15-16 декември 2004 година, Скопје 2005.

Јанчева Ф., Последните дещении со СФРЈ, Скопје 2012.

Малеска М., 'Болни соочувања (причините и последиците од безбедносната криза во Македонија)', New Balkan Politics, No. 5 (2003).

Малеска М., Христова $\Lambda$., Ананиев Ј., 'Споделување на власта нов модел на одмучување во мултикултурните општини', New Balkan Politics, No. 10 (2006-2007). Малески А., 'Причини за една војна (Македонија 2001)', New Balkan Politics, No. 7-8 (2004).

Ризанов Е., 'Македонски мртов капитак', Утрински весник, 7 Мау 2010.

Шкариќ С., Уставно право, Vol. 1, Скопје 1994.

Ljubica JANČEVA, Professor, PhD - Institute of National History, Skopje, Republic of Macedonia. 